Available online at $\quad$ http://www.jfas.info

\title{
STUDYING THE FEATURES OF INDUSTRIAL TOURISM DEVELOPMENT AND OPERATION IN THE REGION
}

\author{
Y. N. Nikulina \\ Orenburg State University, Orenburg, Russia
}

Published online: 08 August 2017

\begin{abstract}
Thematic justification: The urgency of the problem under study is caused by the insufficient developed theoretical aspects and conceptual provisions of the strategy for the formation and development of industrial tourism at the regional level.

Purposes: A purpose of this article is to provide the scientific and methodological support for organizing and regulating the industrial tourism development at the regional level, and the practical aspects of implementing industrial tourism in the modern context.

Study methods: The key method of studying this issue is a content analysis of the websites of organizations involved in the system of industrial tourism organization and promotion in the regions of Russia, as well as a survey of enterprises and consumers in the field of industrial tourism, allowing to consider the features, identify the trends and prospects for its development in a comprehensive manner.

Results of the study: The article reveals the features of industrial tourism development in the regions of Russia based on the analysis of portals of the regional ministries and departments for tourism, websites of the enterprises in the context of federal districts, and information on the excursions to industrial enterprises in the media; the survey results of industrial enterprises and consumers of tourism facilities are provided for analyzing the conditions, the demand for services and the prospects for its development in the region; and the main directions of regional policy are developed in the field of industrial tourism promotion and development.
\end{abstract}

Author Correspondence, e-mail: juliaguzenko@mail.ru

doi: http://dx.doi.org/10.4314/jfas.v9i2s.852 


\section{Practical relevance:}

The study results and developed proposals can be used by the authorities when providing the various purpose-oriented programs for tourist and recreational complex, developing the domestic and inbound tourism at the regional level, and improving the measures aimed at developing and implementing the proposals for strategic development and promotion of industrial tourism.

Keywords: industrial tourism, region, enterprise, consumers, development prospects

\section{INTRODUCTION}

Tourist business is a very promising area of activities and attractive in terms of investment. The tourism industry is the most adaptive and flexible due to the high competition among both companies engaged in the implementation of tourist services and more global tourism destinations such as regions that represent a comprehensive offer in the tourist market for attracting the tourists and receiving the financial and economic positive effects. The high competition stimulates the regions to go beyond the traditional forms of tourism activities and diversify the offer in order to attract the tourists from a more diverse range of target groups, to encourage a repeat visit to the region and tourist destinations (Frolova, Kabanova, 2016).

In recent years, most tourists are attracted not only by the unique natural eco-friendly areas with picturesque landscapes, but also, curiously enough, by industrial facilities. Given the growing popularity among Russians to purchase the permits for short-term tourist routes, we can state that the industrial tourism should take a special place in the list of topical products offered by travel agencies. The industrial tourism is associated with the organization of excursions and regular tours to the advanced operating or formerly operating industrial enterprises of the country. The main consumers of industrial tourism facilities are not only the ordinary tourists, but also pupils, students, entrepreneurs and business leaders, journalists, each of whom will pursue its own goal when visiting the production sites (Nikulina, 2015).

The experience of foreign countries in developing the projects for industrial tourism implementation testifies its effectiveness for both the region as a whole and a certain enterprise. To date, it is quite rare in Russia to find an enterprise that is ready to open its doors to tourist groups and especially do it on a regular basis, rather than as part of the exclusion or partnership development, for example, with a higher education institution. Analysis of the current practices of implementing the elements of industrial tourism shows that it is possible to single out even the entire regions of the Russian Federation, where there is no experience 
of industrial excursions (Garnov, Krasnobaeva, 2012). This is facilitated by a number of barriers, such as:

- $\quad$ absence of specialists for organizing such excursions;

- $\quad$ unsafe industry process for the untrained groups of tourists;

- lack of necessary infrastructure to host the tourists;

- unwillingness to distract workers from the performance of their processing tasks;

- unjustified closed nature of the enterprises;

- desire to hide business processes from the competitors, etc.

Industrial tourism in a particular region, as in the whole country, is poorly developed and does not correspond to the level of its organization abroad (Sklyarenko, Panchenko, Selivanov, Golovenko, 2011). Regulation of issues in the field of industrial tourism by the state both at the federal and regional levels is practically absent. Nevertheless, the experience of several regions shows that the niche for its development remains free, given the significant list of consumers interested in the industrial tourism.

The issues of industrial tourism development in the Russian Federation are inadequately elaborated, there is no clear interaction among the industrial enterprises, the state, the educational organizations and the chambers of commerce and industry in terms of coordinating the joint efforts for its implementation at the regional level. However, it should be noted that this direction, taking into account the existing production base in the territory of any region, can function effectively, and due to its specifics - can give impetus to the development of small and medium-sized businesses, which will also serve as a development factor for a certain region and can become its competitive advantage (Boros, Martyin, Pal, 2013).

It is worth noting that the industrial tourism is a relatively new and interdisciplinary phenomenon, and therefore is poorly designed from a scientific point of view. To date, there has been accumulated a certain regional experience in organizing and conducting the industrial excursions in the form of concrete examples, the samples of which can be used to draw up the regional programs for industrial tourism development and,in general, the strategy for its development in Russia. In this connection, studying the issues of the regional development of industrial tourism is topical and of scientific interest. 


\section{MATERIALSANDMETHODS}

\subsection{Study methods}

The following methods were used in the course of study: theoretical (analysis, synthesis, concretization, generalization, method of analogies, systemic and functional approaches to solving the problem); diagnostic (survey, content analysis of the websites of regional tourism bodies, content analysis of the websites of organizations involved in the organization and promotion of industrial tourism);empirical (method of theoretical and methodological analysis of sources, study of experience in organizing the industrial excursions, analytical method of information collection and processing); methods of mathematical statistics and graphical representation of results.

\subsection{Trial infrastructure of the study}

The experimental base of this study in the form of a survey includes the leading enterprises of Orenburg region, on the one hand, as the industrial tourism facilities, and the target audience of consumers of industrial tourism, on the other hand (pupils, students, tourists, journalists, entrepreneurs, retirees).

\subsection{Stages of the study}

Studying of this issue was carried out in three stages:

At the first stage, the theoretical analysis of a complex of issues related to the specifics and conditions of industrial tourism development at the regional level was carried out, the goals of the main consumers of industrial tourism, as well as the advantages of its introduction into the enterprise and the economy of the region as a whole, and the factors for industrial tourism formation and development in the region were defined, and the influence of regional infrastructure on the level of industrial tourism development was determined.

At the second stage, the system of information support for the process of industrial tourism development was analyzed in the context of regions of the Russian Federation, in terms of mentioning the excursions to industrial enterprises held on a regular basis in the media, and also the portals of regional ministries for tourism development were analyzed in terms of the availability of specific sections on industrial tourism; the peculiarities and tendencies of industrial tourism development in the regions of the Russian Federation were singled out, and the regions' experience on the implementation of projects in the sphere of industrial tourism was reviewed.

At the third stage, an assessment of prospects for the industrial tourism development in the region was given; the conditions and opportunities for introduction of industrial tourism from the viewpoint of enterprises were analyzed, the demand for industrial tourism services was 
evaluated from the viewpoint of consumers, the results obtained were summarized and systematized, the key problems of industrial tourism development in Russia was formulated, and a set of measures for its development at the regional level was proposed.

\section{RESULTS}

\subsection{Industrial tourism: purposes for the region's economy, factors of its formation and development}

Industrial tourism is an organized visit to industrial enterprises, organizations and institutions aimed to meet the cognitive, educational, vocational and other needs (Struzberg, 2013).

The consumers of industrial tourism are not only the tourists who are interested in the industry and history of the region, but also, they can be represented by the delegations, which purpose is the exchange of experience, journalists, pupils, students of profile universities, and current or potential investors (Figure 1) (Nikulina,2016).

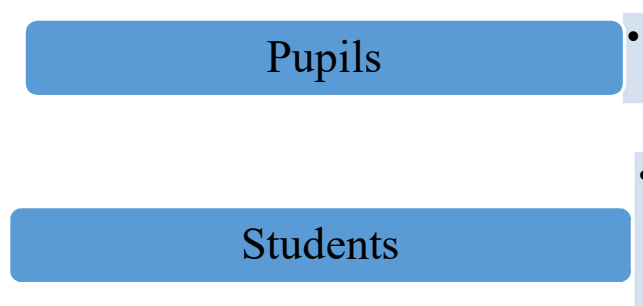

familiarity with the enterprises in the region; obtaining information on the professional occupation

- familiarity with the technological features of production; finding the place of practice; exploring the place of potential employment; getting information about the situation on the labor market

- studying the production process from an economic

Entrepreneurs point of view; exchanging the experience, benchmarking; studying the features and innovations of production

\section{Russian and foreign tourists}

possibility of combining your rest with cognitive purposes

\section{Journalists}

- searching for the newsworthy information

Fig.1. Characteristics of the consumers of industrial tourism 
The role and purpose of industrial tourism for the regional economy can be considered both atthe micro and macro levels.

Advantages of the industrial tourism organization and development at the micro level, i.e. within the concrete organization, are the increasing volumes of production, improving the quality of goods, creating the positive image of the company, promoting the enterprise's trade mark, attracting the investors, searching for the young professionals (Bran, Manea, 2012).

From the viewpoint of the region, the development of industrial tourism is an effective mechanism in creating and promoting a positive image of this territory and an effective marketing tool for attracting the investors and tourists. In addition, projects for the implementation of industrial tourism give impetus to other sectors of the economy in the region, which are associated with servicing the tourist flow, the following can be included here: meal service, accommodation, transportation and other.The introduction of industrial tourism at the regional level positively affects the regional budget, due to tax revenues caused by the increasing turnover, the development of small and medium-sized businesses, investment attractiveness, direct and indirect employment and other factors (Medyanik, Tarabanovskaya, 2016)

In general, the following advantages can be identified for the enterprise and the region, which are resulted in the industrial tourism development (Table 1): 
Table 1. Advantages of the industrial tourism development for the enterprise and the region

\begin{tabular}{|c|c|}
\hline Advantages for the enterprise & Advantages for the region \\
\hline $\begin{array}{l}\text { Creating a positive image of the company } \\
\text { and increasing the level of customer loyalty }\end{array}$ & $\begin{array}{l}\text { Recovering economy of the region as a whole } \\
\text { (the development of medium and small } \\
\text { businesses, increase in tax deductions to the } \\
\text { regional budget) }\end{array}$ \\
\hline $\begin{array}{l}\text { Cash inflow into the individual industrial } \\
\text { production facilities }\end{array}$ & Diversification of the tourist offer \\
\hline $\begin{array}{l}\text { Attracting the potential employees of the } \\
\text { company }\end{array}$ & $\begin{array}{l}\text { Solving the problem of unemployment by } \\
\text { creating new jobs }\end{array}$ \\
\hline $\begin{array}{l}\text { Deepening communication with target } \\
\text { groups of consumers (possibility of } \\
\text { exploring their needs and requirements) }\end{array}$ & Improving the $\mathrm{i}$ \\
\hline $\begin{array}{l}\text { Developing certain aspects of the social } \\
\text { responsibility of business }\end{array}$ & $\begin{array}{l}\text { Increasing the interest of pupils and youth in } \\
\text { working specialties }\end{array}$ \\
\hline $\begin{array}{l}\text { Demonstrating the safety of existing } \\
\text { enterprises, primarily towards the local } \\
\text { population }\end{array}$ & $\begin{array}{l}\text { Indirect stimulation of the development of } \\
\text { related infrastructure }\end{array}$ \\
\hline
\end{tabular}

The formation and development of industrial tourism as a kind of activities is affected by a number of factors that we were conditionally divided into two groups: regional and local.The regional factors determine the potential of the region and contribute to the industrial tourism development, the local factors in turn determine the potential of the enterprise. The regional factors, in our opinion, include:

- availability of the industrial enterprises and plants (industrial tourism facilities) in the given region;

- $\quad$ remoteness of the region from large cities;

- $\quad$ presence of transport and access roads, highways and railways;

- $\quad$ availability of sights in the region;

- $\quad$ historical significance of the region itself.

The group of local factors includes the following:

- $\quad$ uniqueness of the product manufactured (technological process); 
- $\quad$ specificity of the production;

- $\quad$ historical significance of the enterprise;

- $\quad$ investment attractiveness or readiness of the enterprise for investments;

- $\quad$ interaction with authorities and the Chamber of Commerce and Industry.

Each of the presented factors, including local and regional, acts an important role in the industrial tourism establishment and can serve as a catalyst in its development (Kosyakova, 2016). Considering both groups of factors from the viewpoint of the region as a whole, we can conclude that the combination of these factors forms a basis for the development of not only the production, but also the tourism in general.

Thus, it can be stated that the industrial and tourist potential of the region is a combination of regional and local factors required for the formation and development of industrial tourism in a certain region (Copic, S.,Dordevic J., Lukic T, Stojanovic V., Dukicin, S., Besermenji, S., Stamenkovic, I., Tumaric A., 2014).

For the successful and effective development of tourist cluster in the region, in our opinion, the related infrastructure should be developed: accommodation facilities (hotels, inns, hostels, guest houses), catering enterprises (restaurants, cafes, canteens) and trade infrastructure (shopping centers, stores, souvenir shops) (Figure 2). 
- basis of the tour;

- improving the company's image;

Industrial enterprises

- advertising the production and manufactured goods and services.

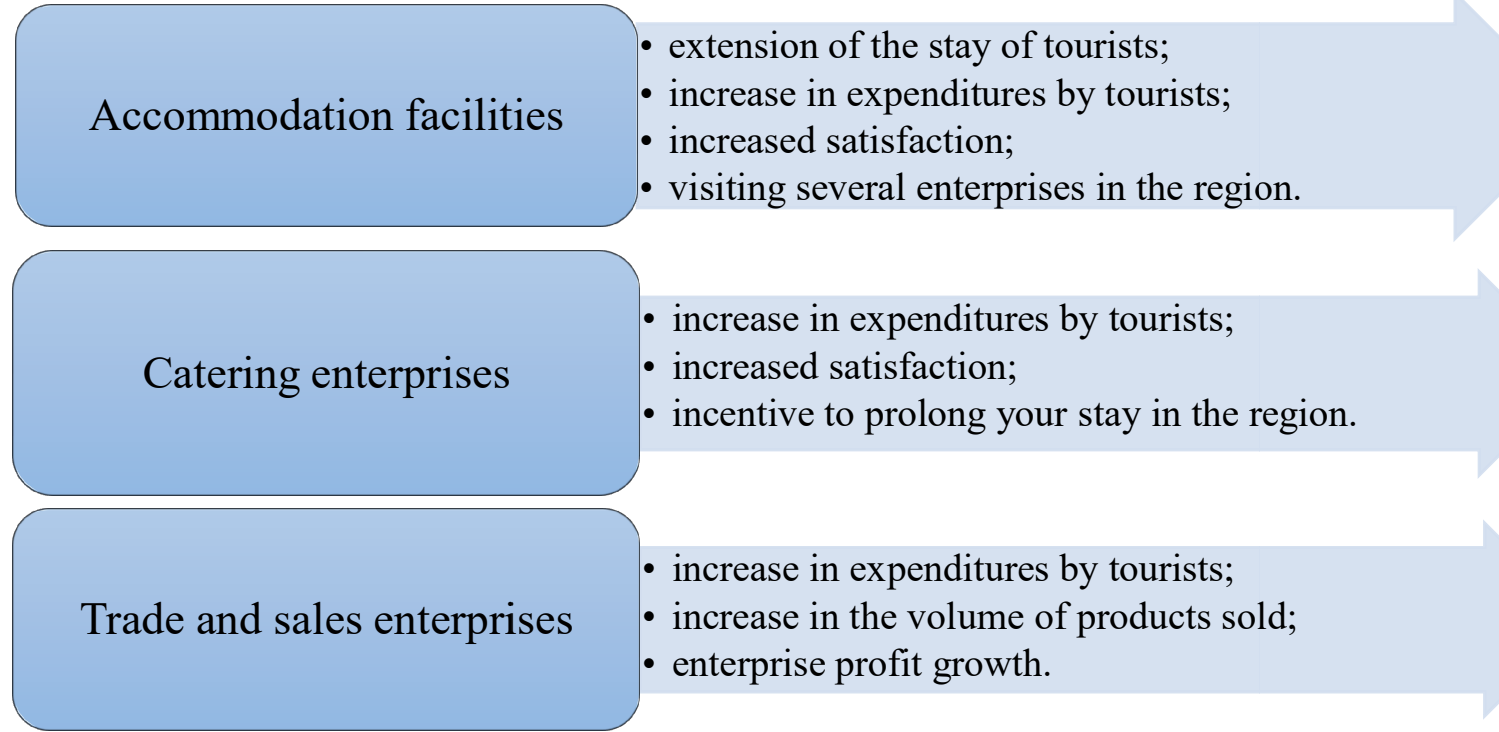

Fig.2. Influence of the region's infrastructure on the level of industrial tourism development

So, we can allocate three scenarios for the development of related infrastructure, which is an integral part of the effective functioning of industrial tourism.

The first scenario implies the joint establishment of necessary infrastructure in stages and gradually with the development of industrial tourism. At the moment when the enterprise makes a decision to open the doors for tourists, provide a specialized tour and attract the tourist flow - an impetus for the development of small and medium-sized businesses is created. Entrepreneurs are starting to invest their money in the development of infrastructure, particularly in service facilities (catering and accommodation), and the trade and service enterprises (stores, shopping centers and souvenir shops) (Koreshkov, Derevnina, 2015).

The development of industrial tourism in the second scenario is the formation of an industrial tour by an enterprise in the region, where already there is a necessary infrastructure. This type is typical for the tourist destinations and large cities, already providing some kind of tourism services and having their own tourist flow. In this case, the task is to redistribute the flow of tourists to industrial facilities, attract new interested tourists. At the same time, the entire infrastructure is already operating, and you only need to include it in the tour, by directly or indirectly involving in it. 
The third scenario is typical for industrial centers. These regions are characterized by a high level of industrial development, but the lack of infrastructure as such. In this case, the industrial tourism will give impetus to the development of small and medium-sized businesses, which in turn will gradually provide the necessary infrastructure (Volkov, Morozova, 2016).

Thus, the analysis of factors establishing the industrial tourism provides us with a characteristic of those conditions that can contribute to the most effective development of this kind of tourist activities. In turn, the development scenarios determine which of the groups of factors - local or regional, is worked out to a greater extent in the given region, and investments into which of them will give the greatest effect.

\subsection{Features of the industrial tourism development in the regions of Russia}

Industrial tourism is a popular destination in the cities of Western Europe and America, which is especially developed among the single-industry towns with a limited choice of sights that could be an object of tourist interest, but have enterprises with a rich history, famous brand or interesting technology of product manufacturing (Jonsen-Verbeke, 1999). Currently, the industrial tourism is developing abroad not only in the single-industry towns, but also in the large cities, as a complementary component of the tourist destination, which is able to diversify the offer for tourists (Otgaar A., 2014).

Industrial tourism is also developing in the Russian cities, as evidenced by information messages and the inclusion of visits to manufacturing enterprises in such events as "Night of Museums", "Week without Turnstiles", which clearly indicate that enterprises participate in the tourist activities of cities (Volkov, 2015). However, in the works of researchers, the characteristics and analysis of the peculiarities for industrial tourism development in the Russian regions are not provided.

The Internet, being the main source of information and the largest information field, makes it possible to assess the presence of any mention of industrial tourism in various regions. We carried out an analysis in the context of each region of the Russian Federation, which included the following units: content analysis of the websites of regional tourism authorities, content analysis of the websites of organizations involved in industrial tourism in terms of information about industrial excursions and mention of industrial tourism in the regional mass media.

The results of this study showed that only in 10 regions of the Russian Federation (12\%) there is some information on the implementation of industrial tourism, facilities of this sphere, or 
current industrial excursions. In the remaining 75 regions $(88 \%)$, it can be stated that the territorial tourism bodies do not work in this direction or such information is not provided.

Analysis of the websites of enterprises and major tour operators at the level of constituent territories of the Russian Federation allowed us to assess the regularity of industrial excursions in the regions. According to the results of this study, in 44 regions of the Russian Federation $(52 \%)$ the industrial excursions are held constantly or have a non-permanent nature. Among the main reasons for that is, in our opinion, the lack of necessary infrastructure for holding tourists and the fact that most large enterprises in a given region are strategic and high security facilities.

The leader in the set of regions, wherein there are the enterprises conducting the industrial excursions on a regular basis for various groups of tourists, is the Volga Federal District (Yashalova et al., 2017).

For example, the Republic of Tatarstan is implementing a project on the industrial tourism development, approved by the Chairman of the Board of Machine-Building Cluster in the Republic of Tatarstan, and supported by the Naberezhnye Chelny Investment Promotion Agency.The objective of this project is to provide the vocational guidance for students, increase the image of the organization, and attract the qualified personnel. The following four enterprises are involved in the project: Alekseevskaya art weaving factory, Tatspirtprom JSC, Ford Sollers Holding Plant, Kamaz PJSC (Kadyrov,2012).

The Chuvash Republic has experience in the implementation of industrial tourism by Novocheboksarsk affiliate of "SUN InBev". As part of its implementation, all adults can visit the plant and become familiar with the production process. The plant regularly arranges an Open Day.

Industrial tourism is one of the most promising directions of tourism industry development in Samara region. A number of industrial facilities in the region - such as the Samara Bakery and Confectionery Plant, Pepsi and Coca-Cola plants, "Teplichny"State Farm - conduct the excursions to production facilities. Most often, the excursions are held at the Baltika-Samara plant. The concept of open production was laid here at the construction stage, which allows you to acquaint with the work of the food enterprise without violating the norms of industrial safety and strict sanitary conditions. Baltika-Samara Brewery is visited annually by more than 2.5 thousand of adult visitors as part of familiarization or thematic excursions (Grigorenko, Kazmina, 2015). 
In Penza region, a regional project of industrial tourism "PromTur" is being implemented among the students of the region in order to form their understanding of the real work of enterprises and the early vocational guidance. As part of the project, the students attend the steadily growing enterprises. This allows them to compose their own ideas about different types of plats and helps in career counseling. Among the enterprises that regularly host schoolchildren are the groats factory "Tamala-elevator" LLC, "Kuvak" plant, "Okolitsa" LLC, and others.

In the Orenburg region, there is a sufficient number of enterprises and organizations that are the potential and operating facilities of industrial tourism routes, which are oriented toward satisfying the interests and goals of a sufficiently large number of consumers (Struzberg, Dokashenko, 2014).

For example, within the interaction with the business community during the academic year, the Orenburg State University (the OSU) annually organizes the industrial excursions for the potential entrants and students to the profile partner enterprises of the university. In addition, the OSU for the first time in April 2017 took part in the all-Russian vocational orientation project "Work in Russia!", which is aimed at increasing the prestige of working and engineering professions in demand for the domestic industry. At the invitation of the University, 55 enterprises took part in these event, among them: South-Ural branch of LLC Gazprom Energo, JSC "Invertor" Plant, PJSC "IDGC of Volga" branch of "Orenburgenergo", LLC "A7 Agro-OMK", LLC "Research and Production Enterprise "Energia". In total, 65 excursions were organized and conducted, in which 1200 students and university professors took part.

Excursions to the garbage sorting complex of Orenburg become popular, especially since 2017 was declared the "Year of Ecology". About a half-hundred excursions were conducted for the garbage sorting complex over the last 7 months. For this purpose, the enterprise purchased a special school bus. The main purpose of such excursions is to familiarize with the processing technology, teach the children, and their parents through them, in separate collection of garbage, which will positively affect the ecology of the region.Specially for the excursions, the enterprise issued the methodological materials - separately for the senior and junior school level.

The Orenburg brewery plant "Kraft" conducts regular free excursions for all comers, during which the excursionists can learn about the main stages of the company's history and its activities, familiarize with the technologies of making drinks and visit the main production workshops. This policy of openness underlines that the manufacturer has nothing to hide and 
production is carried out exclusively on technology. The excursions are held in groups of 15 people, designed for both children and adults. The company's website provides a booking function.

At the initiative of the Government of Orenburg Region, in September 2016, as part of the events organized for the "Day of the Elderly", the Orenburg enterprises held "Open Doors" for elderly citizens who want to get acquainted with the situation of industrial and agrarian sectors in the region's economy, see modern technologies, new equipment, and conditions created for the labor collectives. The retirees got acquainted with the work of two enterprises in the field of hothouse economy: LLC "Flowers of Orenburg" located in the village of Chernorechye and JSC "Plant of Drilling Equipment".

In April 2017, the State Unitary Enterprise of Orenburg region "Airport Orenburg" - Museum of Civil Aviation - took part in the nationwide "Night of Museums". Orenburg citizens and visitors of the city, totally almost 3 thousand people, got acquainted with the exhibits of aircraft and helicopter. Experts of the aviation industry told about each type of aircraft and answered the questions of interest. For the organized groups, there were excursions with informative stories about the life of the Orenburg aviation enterprise in different years, technical features and characteristics of the aircrafts represented in the exposition, and many other things.

Excursions to the enterprises of Orenburg region are included in the program of meetings, conferences, business trips, and the UralExpo LLC includes such excursions to the profile exhibitions plan. So, while visiting the city of Orenburg on business, the Finance Minister Anton Siluanov, and the Industry and Trade Minister - Denis Manturov, could visited three regional facilities: JSC "PO "Strela", OJSC "Drilling equipment factory" andthe Industrial park "Orenburg down shawl".

Also, along with Volga Federal District, the industrial excursions take place in other federal districts (Belentieva, Naruta, 2015). In the North-West Federal District, the industrial enterprises-brands are the Leningrad Nuclear Power Plant, the Shipyard Severnaya Verf, the Khokhloma Painting Plant, the Baltika Brewery, the Hyundai Automotive Plant, the St. Petersburg Metro, and others. (Dmitriev, 2016), (Timofeev,2014).

As part of the analysis of information support for the development of industrial tourism in the regions of the Russian Federation, we took the fact about the of industrial tourism organization and development in the region mentioned in the media as an additional indicator. 
Analysis of the Internet space has shown that in the mass media, there are frequent references to the industrial tourism. In 58\% - or 49 regions of the Russian Federation, they highlight the problems and experience in the implementation of elements of industrial tourism, the need for its development and talk about attempts to introduce and make it a mass character. The brandleaders of the territories are Belgorod region, Bryansk region, Ivanovo region, Moscow region (Pogorelov, 2012).

Results of the study of information support for the industrial tourism development, in general, have shown that it is not developed everywhere, in some regions there is even no mention in the media, not to mention research in this field, and information posted on the website of the regional authorized body regulating the tourism activities.

\subsection{Evaluation of the prospects for industrial tourism in the region: the viewpoint of enterprises and consumers}

\subsubsection{The analysis of conditions and prospects for industrial tourism development from the viewpoint of enterprises}

Studying the prospects for industrial tourism development from the viewpoint of enterprises as its main objects is based on the results of a survey of regional enterprises in the context of the following aspects: assessment of the level of awareness and interest in the tourism industry development, analysis of the experience of organizing the industrial tours, availability of technical facilities for hosting the tourist groups, identifying the groups of target audience among the consumers of industrial tourism services, expectations of enterprises from the organization of excursion tours, identification of the main barriers in hosting the tourists.

The survey was attended by 83 leading enterprises of Orenburg region in various fields of activities: electric power industry - 6\% (5 companies), manufacturing industry $-15 \%$ (12 companies); food production - 8\% (7 companies); IT technology - 8\% (7 companies); trade industry - 12\% (10 companies); service, housekeeping, maintaining - 12\% (10 companies); transport, shipping - 6\% (5 companies); construction, real estate - 18\% (15 companies); and finance, insurance, banks - 15\% (12 companies).

The results of survey showed that only $40 \%$ of the enterprises surveyed had ever heard of industrial tourism, a quarter of respondents is "not sure" and 35\% of all respondents had never heard of this direction of tourism activities. The analysis of responses by areas of activities had showed that enterprises working in the field of manufacturing, electric power, housekeeping, maintaining and food production are more familiar with the concept of "industrial tourism". 
Almost half of the surveyed representatives of enterprises (48\%) showed the interest in industrial excursions and would be willing to visit the enterprises, $13 \%$ of all respondents flatly answered "No", and 39\% were not sure. The greatest interest in industrial excursions was shown by enterprises working in the field of industrial and food production, finance, insurance, banking, and IT technologies.

The initiator of interaction between various groups in the field of industrial tourism is always the industrial enterprise itself, since it initially creates the preconditions for the occurrence of an industrial tourism product, which are transformed into the final product (Hospers, 2002). On a question to respondents: "Was there an experience of organizing industrial excursions at your enterprise?" - $42 \%$ of enterprises responded positively, a quarter of respondents $(24 \%)$ could not answer this question, and 34\% of respondents said that such excursions had not been conducted before (Figure 3).

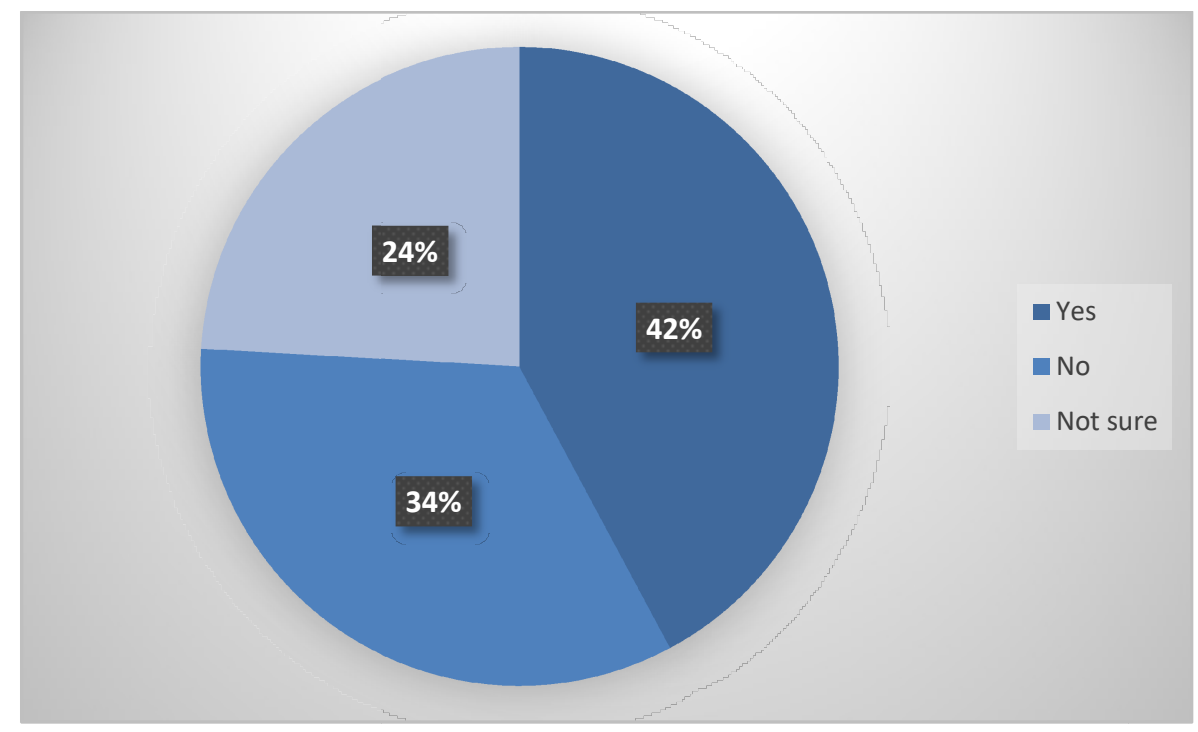

Fig.3. Was there an experience of organizing industrial excursions at your enterprise?

Based on the data of all the companies surveyed, as well as the content analysis of websites of the respondent enterprises, it was revealed that the vast majority of all industrial tourism products in the Orenburg region are production and technical, that is, they are based on the demonstration of production process (Nikulina, Struzberg,2015). 


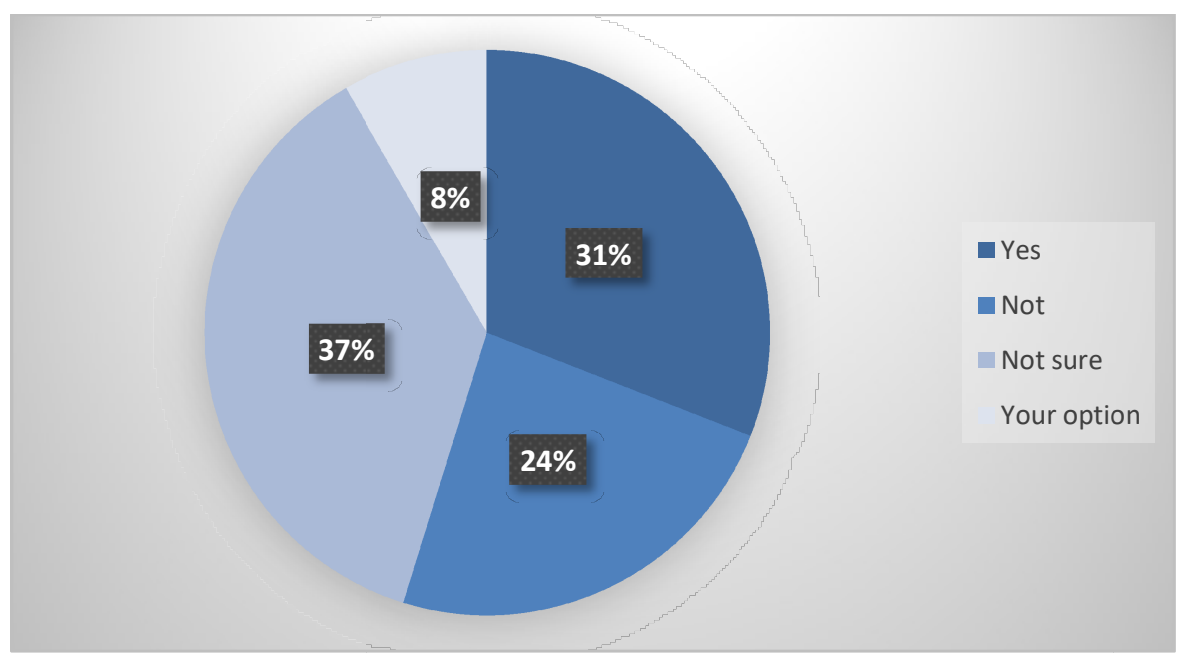

Fig.4. Are there the technical capabilities to host tourist groups at your enterprise?

Answers to the question of technical capabilities to host the tourist groups were divided by the enterprises participated in the survey as follows.31\% of companies have enough opportunity to open their doors to tourists. Mostly, the positive response was given by the large enterprises working in the field of electric power and industrial production. $24 \%$ of respondents said that they do not have such capabilities - mostly these were the companies from a number of industrial enterprises and construction and real estate companies. $37 \%$ of enterprises found it difficult to answer this question. $8 \%$ of respondents gave their option (four companies cannot host the tourists, due to the fact that such a facility is closed and high security, or to visit it, you shall satisfy the certain factors, such as health books; two companies said that in view of the specifics of their work, they have nothing to show for tourists; and one company cannot host the tourists all year-round, but only in a certain calendar period).

While the study, the groups of target audience, which the industrial enterprise attracts or wants to attract, directing its communications and announcing the development of industrial tourism products, were also identified (Figure 5). 


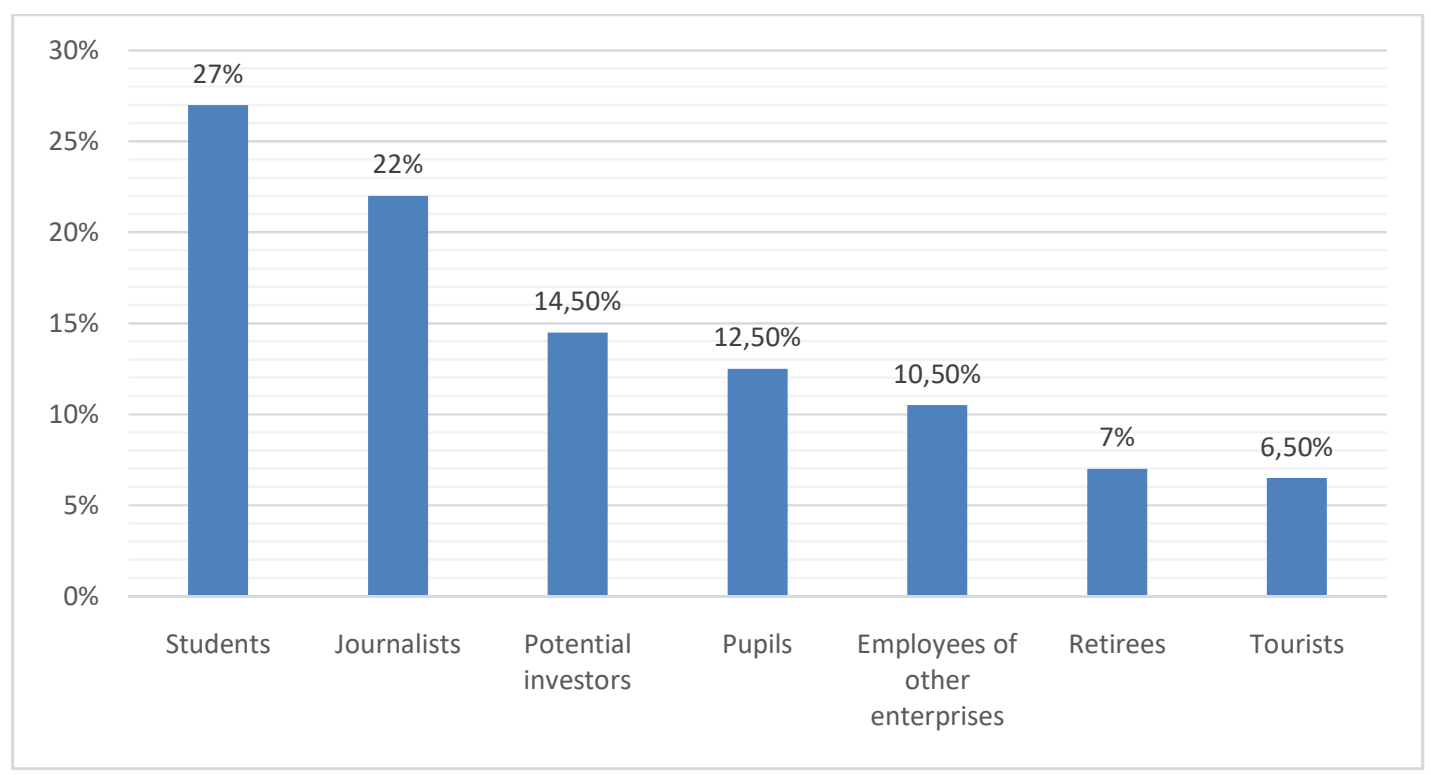

Fig.5. For which categories of consumers would you be willing to organize an excursion at

$$
\text { your site? }
$$

The overwhelming majority of companies believe that students and journalists would benefit most as excursionists: $27 \%$ and $22 \%$ of respondents, respectively. The third place is occupied by potential investors $-14.5 \%$, then pupils $-12.5 \%$, and then employees of other enterprises, retirees and ordinary tourists.

In order to identify an understanding of the possible positive effect for the company from the organization of industrial excursions, the respondents were asked the following question "Indicate, what do you expect from the organization of excursion tours at your enterprise?" (Figure 6). 


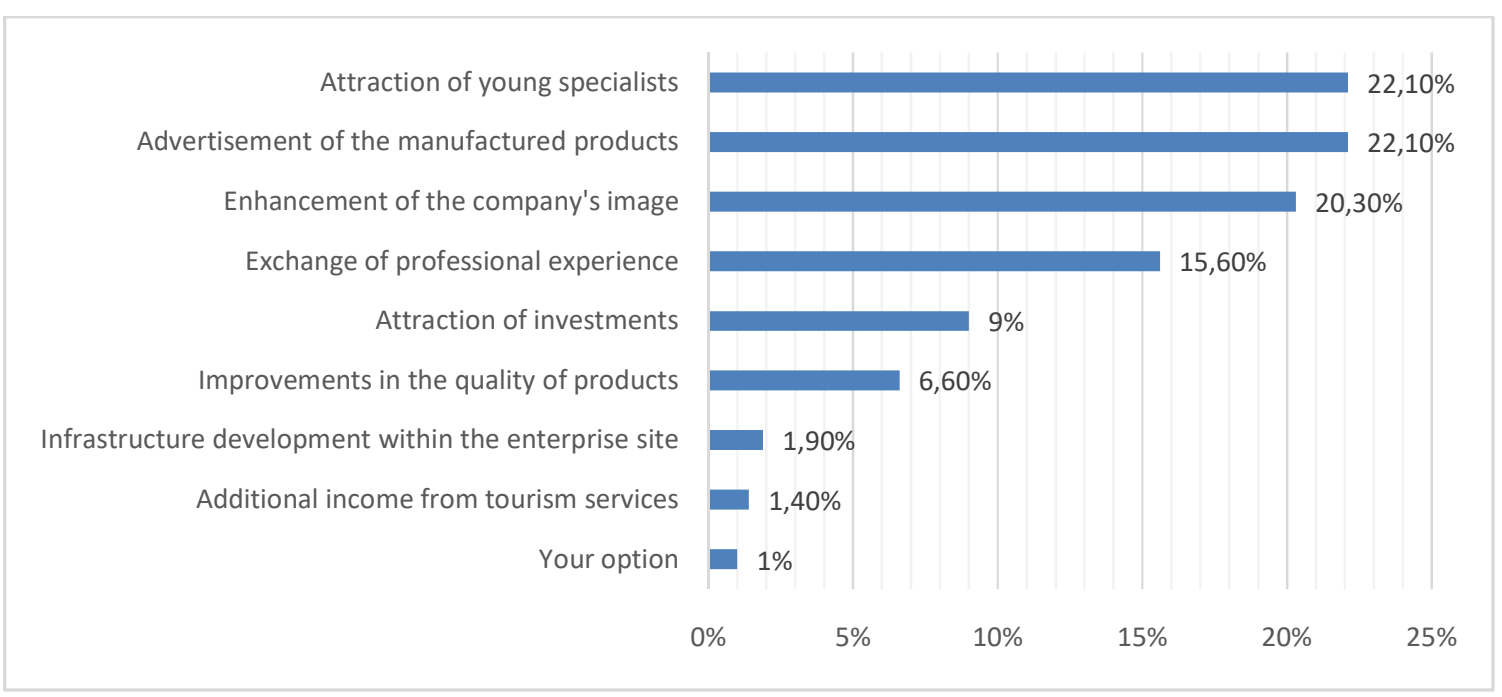

Fig.6. Indicate, what do you expect from the organization of excursion tours at your enterprise?

Thus, the three most important expectations among the companies-respondents were revealed. Advertising the organization and products manufactures is most of all important for the businesses in the sphere of trade, service, housekeeping, maintaining, construction and real estate. The attraction of young specialists is of interest for the electric power industry, manufacturing industry, and IT - technologies. The organization of excursions aimed to improving the image of the company is planned to be carried out by the enterprises of food production, financial and banking sphere (Uskova, Egorov, Leonidova,2016).

In the conclusion of assessing the prospects for industrial tourism development, the respondents were asked a question -"What can be the main barrier in hosting tourists at your organization?"Respondents' answers to this question were distributed as follows:31.5\% of enterprises indicated the lack of specialists for organizing such excursions (enterprises working in the field of IT-technologies, financial and banking spheres); $29.3 \%$ noted as a barrier - the lack of necessary infrastructure for holding the tourists (enterprises working in the field of trade, construction and real estate); $14.2 \%$ of the respondents drew their attention to the insecurity of production process for the untrained groups of tourists (enterprises working in the sphere of industrial production and construction); and $12 \%$ of respondents indicated a reluctance to distract employees from their performance of production tasks (organizations working in the field of service, housekeeping, maintaining, as well as transport and shipping). Many companies did not find the right answer in the questionnaire and 
provided theirs. The main barrier, in their opinion, is that the facility is a high security or strategic - 13\% of companies, and one company considered that the specificity of the industry in which it operates does not involve any facilities that could be of interest to the tourists.

\subsubsection{Analysis of the demand for industrial tourism services from the viewpoint of consumers}

The main focus group of consumers for the educational services, who took part in the survey, were students and pupils - 33\% (114 people) and 32\% (110 people), respectively, the second largest group of respondents were tourists - 26\% (90 people). The percent of entrepreneurs, media representatives and retirees was $3 \%$ of all respondents.

Figure 7 shows the results of analysis of the opinion of various categories of consumers about the industrial tourism. $35 \%$ of respondents heard about the industrial tourism, $49 \%$ responded negatively, and $16 \%$ of respondents are not sure.

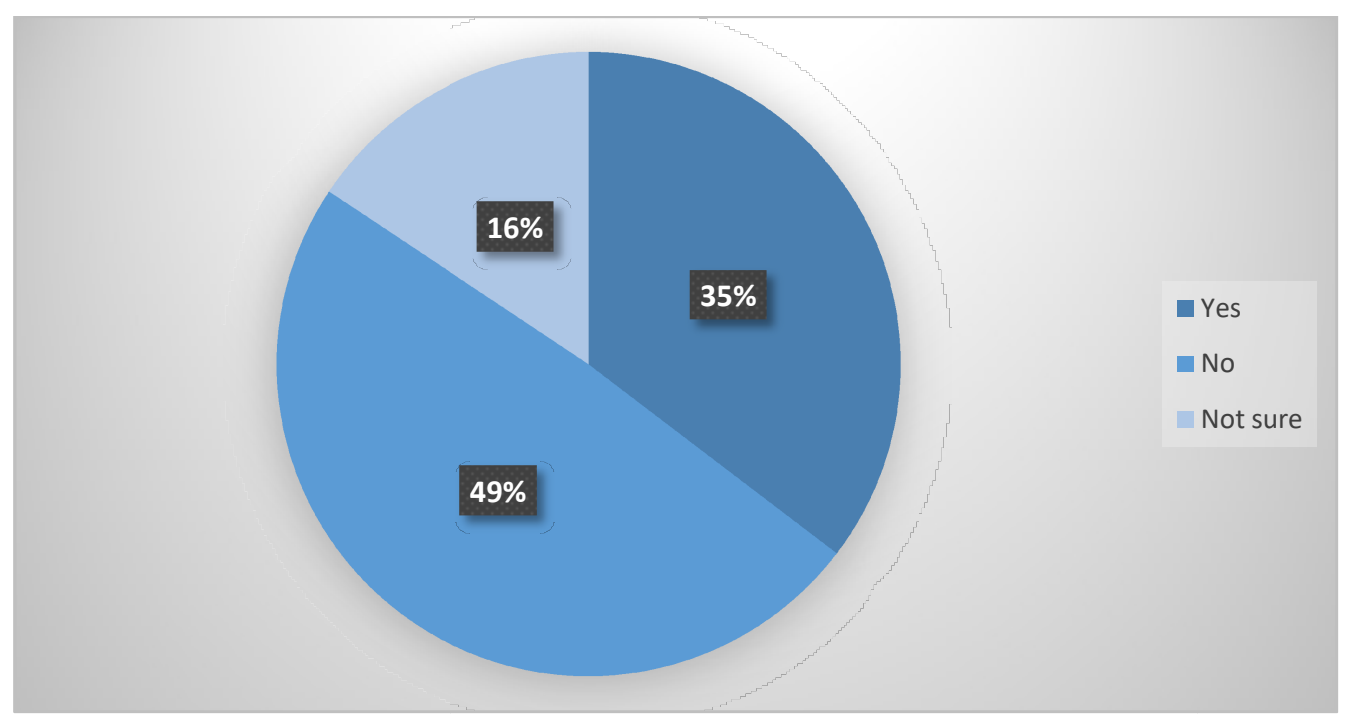

Fig.7. Have you ever heard about the industrial tourism?

As it turned out, $67 \%$ of media representatives, $43 \%$ of students, $42 \%$ of tourists, $24 \%$ of pupils, $13 \%$ of entrepreneurs, and $7 \%$ of retirees heard about the industrial tourism.

To determine the interest of respondents in industrial excursions, the following question was asked, the characteristics of response to which are presented in Figure 8. The predominant part $(79 \%)$ shows its interest in this kind of tourist activities, $8 \%$ are not interested in the industrial excursions, and $13 \%$ of respondents find it difficult to answer. 


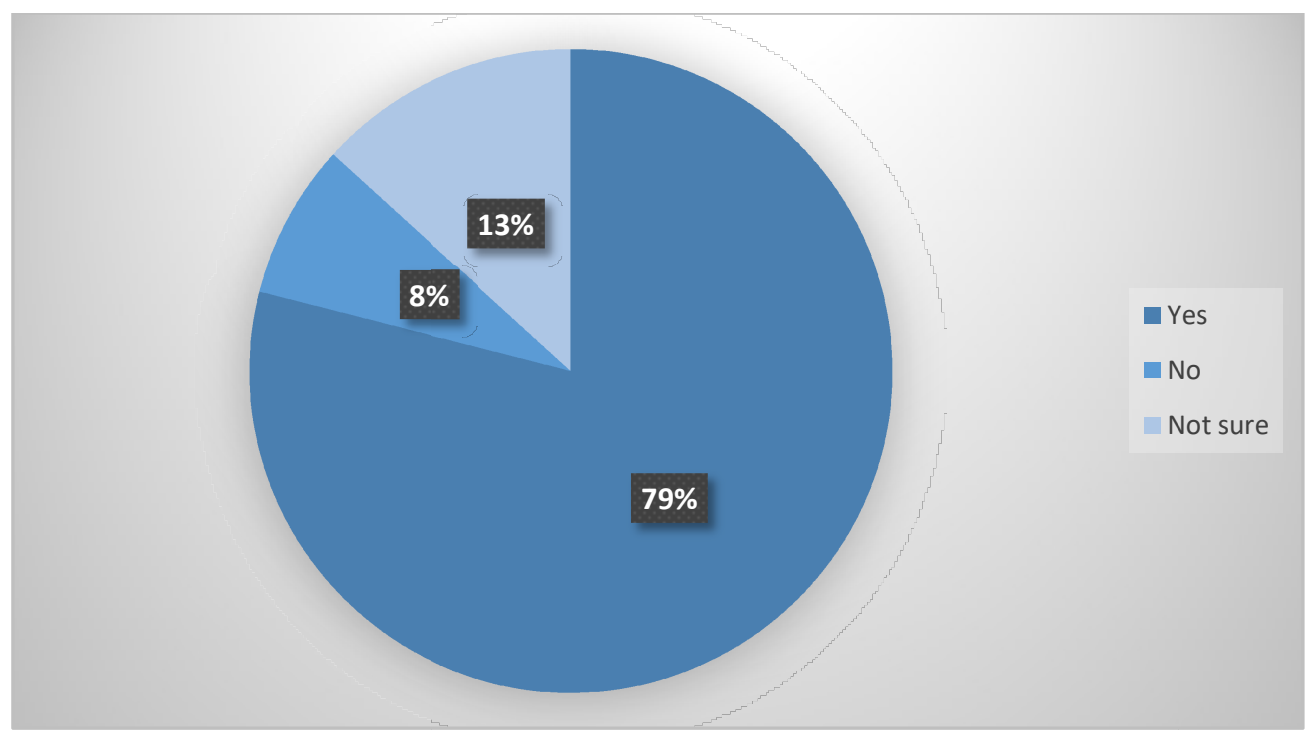

Fig.8. Would you be interested in excursions to an operating enterprise or production plant?

In the context of consumer groups, it should be noted that the industrial excursions are more of interest to the media representatives - $93 \%$, tourists $-85 \%, 81 \%$ of students are also interested in excursions to the operating enterprises, slightly less pupils - $74 \%, 80 \%$ of entrepreneurs and $53 \%$ of retirees.

Figure 9 shows the areas of enterprises' activities that are most interesting for the potential tourists. - Food production, manufacturing industry and IT are among the demanded areas of activities. 


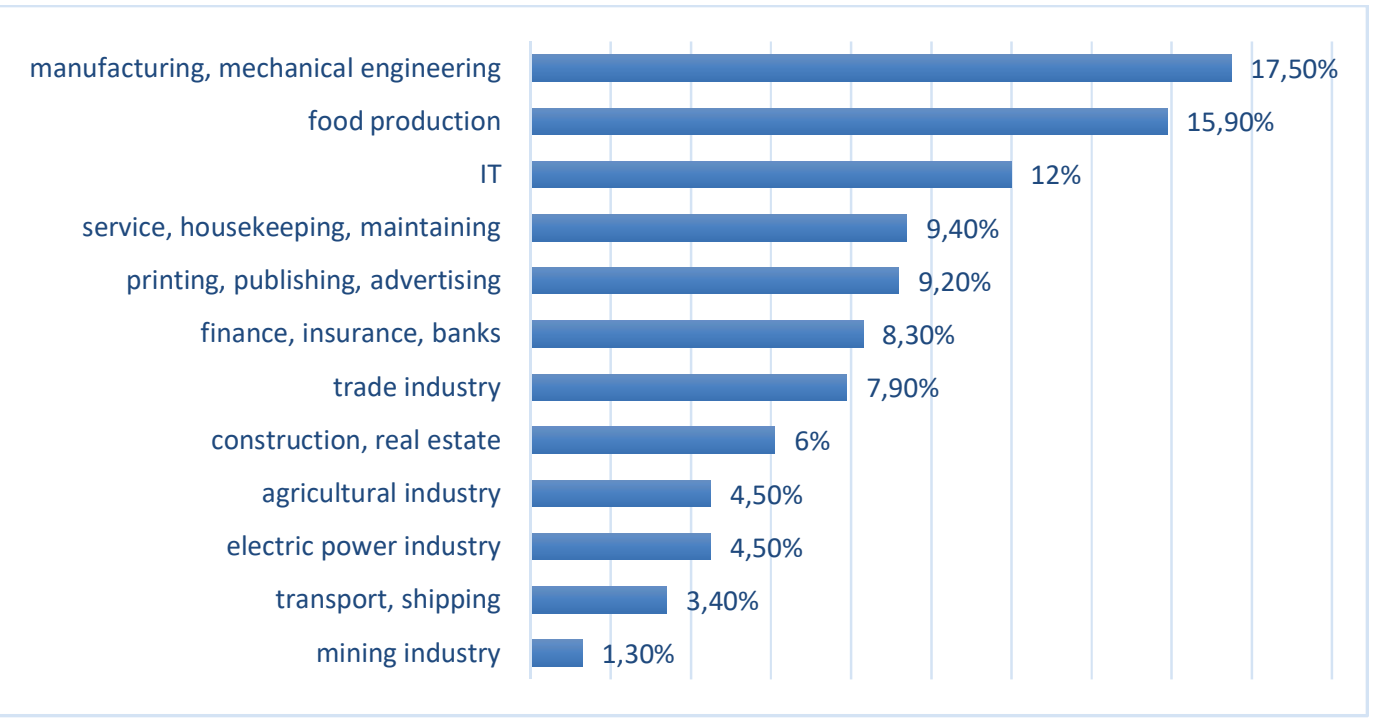

Fig.9. What kind of business activities would you prefer to do, when choosing an excursion tour?

The goals of consumers, when visiting the enterprises, are shown in Figure 10.

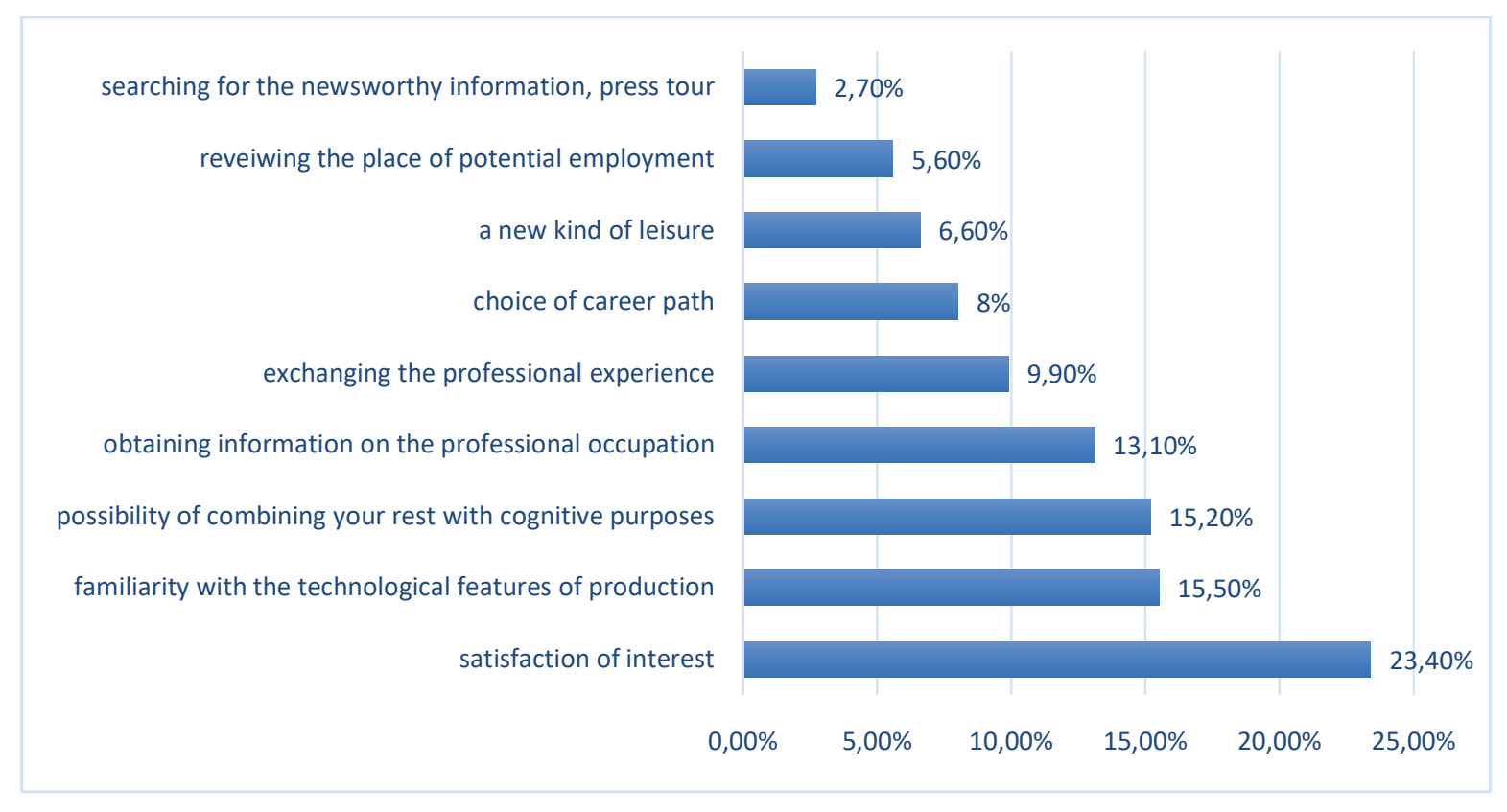

Fig.10."What would be your goal in the case of a visit to an operating enterprise?"

For the pupils, tourists, students and media representatives, the main goal when visiting the industrial enterprises will be to satisfy their interest. For entrepreneurs, it is important to 
exchange the professional experience and the opportunity to combine rest with cognitive purposes, for retirees - it is a new kind of leisure.

All focus groups unanimously singled out the production itself as the most interesting aspect of the excursion. Also, the students are also interested in the uniqueness of products manufactured and the opportunity to communicate with the enterprise's employees. The pupils were also interested in the uniqueness of the products and the professional guide. The entrepreneurs, media representatives and tourists, besides the production itself, were interested in the opportunity to communicate with the enterprise's employees and the specificity of products manufactured, the retirees - the company history and the professional guide.

The presented analysis gives a clear description of what they want to see, both consumers and enterprises. However, on the part of both categories, the involvement in industrial tourism, which we investigated - in general, there is an interest in this kind of tourist activities. Also, it should be noted that for the consumers it's important to have the additional and accompanying infrastructure at the enterprise and in the region.

\section{DISCUSSIONS}

The issues of industrial tourism development are reflected in the works of a number of scientists, however, the theoretical foundations of industrial tourism, taking into account the current economic development and social changes in domestic and foreign studies, have not been fully provided.

Currently, the scope of domestic tourism, as well as many other sectors of the economy, experienced the all phases of systemic economic crisis. At the same time, due to the current economic situation in the Russian Federation, anti-Russian sanctions, the priorities of Russians began to shift towards the domestic tourism. The study of relevant problems by domestic specialists has revealed both a set of interesting trends and a number of acute problems. In particular, those are denoted by T.N. Grigorenko and L.N. Kazmina (2015), T.B. Uskova, V.K. Egorov and E.G. Leonidova (2016), N.N. Yashalova, M.A. Akimova, D.A. Ruban, S.V. Boyko, A.V. Usova and E.R. Mustafaeva(2017).

A number of foreign researchers study and systematize in their works the concept of industrial tourism in detail. The conceptualization of industrial tourism is disclosed in the works by E.A. Frew (2008) and Lee, C.-F. (2016), in which it's noted the need for a broad interpretation; at the same time, it is said that this type of tourism requires the special approaches to management, as involves a combination of tourism and production activities. A. Otgaar 
$(2012$, 2014)has identified three prerequisites that are sufficient to ensure the interest of business owners to participate in industrial tourism. These include a sufficient amount of tourist flow, the possibility of co-branding (combined franchising) of production, the potential of industrial tourism products.The study the group of Serbian experts,Garaca, V., Trifkovic, A., Curcic, N., and Vukosav S. (2014), showed that the problems of industrial tourism development may be associated with inadequate support by the local population, the need for complex infrastructure, the uncertainty in the authenticity of places of interest. It is interesting to note that the industrial tourism is regarded not only as a tool for activities diversification in the existing enterprises, but also as a means of rehabilitation of the industrial decline areas. Bujok, P., Klempa M., Jelinek J., Porzer M., and Rodriguez Gonzalez M.A.G. (2015) highlight that as a result of the implementation of elements of industrial tourism, the industrial facilities are gaining the value as heritage sites, and the region itself is beginning to be perceived as a culturally significant, modern, innovative.

Special attention should be paid to the experience of studying the industrial tourism in China, which was analyzed by Y. Jia (2010). In particular, the marked work provides the concept of the need to develop a truly unique tourism product, the specifics of which are related to the features of production and the possibilities for their rethinking when involving in tourism. Moreover, in Chinese science they are talking about the so-called "experience tourism" (provided inEnglish terminology), which is designed to provide some sort of tourist involvement in the production.

Among the domestic experts, the theoretical rationale for the development of industrial tourism was proposed by S.K. Volkov and I.A. Morozova (2016), A.P. Garnov and O.V. Krasnobaev (2012),A.V Medyanik and S.V. Tarabanovskaya (2016), N.V. Pogorelov (2012) and G.V. Struzberg (2013).

According to S.K. Volkov (2015), who analyzed the German experience, the development of this kind of activities is closely related to the application of regional marketing strategies, taking into account the interests of stakeholders. The routes of industrial tourism within the Orenburg region were proposed by G.V. Struzberg and L.V. Dokashenko (2014).

For the Primorye Territory, the potential of this kind of activities was also reviewed by T.N. Belentieva and Ya.S. Naruta (2015),R.V. Kadyrov (2012) - for the Republic of Tatarstan, A.A. Kosyakova (2016) - for the Vologda region. According to G.S. Dmitriev (2016), M.V. Koreshkov and S.E. Derevnina (2015), Yu.N. Nikulina $(2015,2016)$, this type of tourism is quite capable of increasing the supply of production with highly qualified personnel, as well as providing a communication between the industry and the educational 
environment.Following the logic of these arguments, one can add that these personnel will also be additionally motivated, which is especially important in the Russian context.S.A. Sklyarenko, T.M. Panchenko, I.A. Selivanov, M.V. Golovenko (2011) show how the stand-by enterprises of a separate industry (in this case, the sugar industry) can be used for the purposes of industrial tourism, which in turn facilitates the transition to a postindustrial economy. Based on the example of St. Petersburg shipbuilding cluster, N.V. Timofeev (2014) successfully demonstrated the contribution that the industrial tourism can make to improving the region welfare. At the same time, he notes that this kind of activities favors the innovative production activities.

The analysis of scientific literature and practice of implementing the industrial tourism projects in the regions of Russia allowed us to make the conclusion that the study of the specifics of industrial tourism development and functioning at the regional level is not given due attention. Those skilled mostly consider the certain examples of using the potential of industrial tourism. At the same time, the theoretical analysis of a set of issues related to the trends in the industrial tourism development at the regional level has allowed us to identify the categories of its main consumers, to determine the advantages of its implementation and industrial tourism for a particular enterprise and the region as a whole, and to formulate the factors for its formation and development.The study of the demand for industrial tourism services from the perspective of enterprises and consumers has made it possible to systematize the key issues of this field, and to assess the prospects for its development in the modern context.

\section{CONCLUSION}

The analysis conducted in the field of regional specifics of the industrial tourism organization made it possible to distinguish the following features of its development and functioning.

Firstly, there are a large number of barriers that are determined by the specifics of industrial enterprises' activities and the non-core tourism activities for them, as well as the presence of additional conditions allowing to ensure the safety of both the visitors themselves and the tourism destination.

Secondly, the industrial enterprises are oriented to several target groups of potential consumers, but there is a limited number of channels for the consumers interacting and attracting: through publications on the web portals with announcements of events, through the presence of their own groups in the social networks, through the travel agencies. 
Thirdly, there is a fairly strict requirement for the product - excursions, according to which a part of or a whole excursion should be aimed to the demonstration or the story about the production process in the enterprise.

Fourthly, for the individual consumers, the most interesting and attractive excursions are those they can visit on their own, not as a group.

Summarizing, we can formulate a set of practical recommendations for the industrial tourism promotion and development in the region:

- further in-depth analysis of the world practice in the industrial tourism development is required. Benchmarking of the best practices will make it possible to provide the recommendations acceptable to the Russian conditions for the active use of industrial tourist products, while diversifying the tourist offer and forming a positive image of the region and business structures;

- inclusion of this area of tourism activities in the strategic plans of territories development. The development of industrial tourism, of course, should be based on stimulating the interest of entrepreneurs to do this. However, the elements of state support (promotion, partial funding, etc.) should be legislated;

- creation of a working group to address issues related to the project development, the definition of measures aimed at attracting the tourists, the organization of interaction among the industrial enterprises, educational organizations and tourist agencies;

- formation of an information space that reveals the opportunities for regional industrial tourism, primarily through the websites of departmental organizations responsible for the development of tourism and entrepreneurship, as well as through the regional media. It is necessary to understand that at the first stage of industrial tourism formation and development, the main consumers will be the residents of the territory, and therefore the territorial government should take on the task of its promotion;

- focus on the information transparency throughout the production and sales activities of companies should be practice for the business entities in the region. This will facilitate not only the establishment of a system of communication with the potential consumers, but the formation of a loyal attitude towards the enterprise, which, ultimately, will affect its competitiveness and sustainability in the long term;

- development of the public-private partnership, which is expressed as follows: strengthening the cooperation level among the travel business entities, industrial enterprises and the regional chambers of commerce and industry, at the development of tourism infrastructure, while forming a single brand of the territory. 
The above actions will make it possible to systematize the sphere of industrial tourism more wildly and focus on supporting and developing its strengths, be oriented towards the prospective enterprises that have the greatest opportunities for development and improvement.

These aspects of the article can be useful to scientists - economists, employees of the executive authorities in the territorial entities of the Russian Federation, researchers, teachers of economic specialties, post-graduate students, master's students involved in studying the industrial tourism development in the region.

In the course of the study, some new questions and problems arose and now shall be solved. Further work is needed to provide the organizational and economic mechanism of industrial tourism development at the regional level, which is based on the interaction of objects and subjects, the modernization of tools and forms, and aimed at managing and promoting the development of industrial tourism at the municipal and regional levels.

\section{ACKNOWLEDGMENTS}

The study was funded by the Department of Humanitarian and Social Sciencesat Russian Foundation for Basic Researchand the Government of Orenburg region (Project No. 17-1256023 "The provision of new approaches to the industrial tourism development in the region (in case of Orenburg region)").

\section{REFERENCES}

1. Belentieva, T.N., Naruta, Ya.S (2015) Analysis of industrial tourism state in the Primorye Territory.Bulletin of modern science, 11-2,23-28 (In Russian: Analiz sostoyaniya promyshlennogo turizma v Primorskom kraye).

2. Volkov, S.K., Morozova, S.K. (2016) Is it necessary to develop the industrial tourism in Russia? Topical scientific research in the modern world, 8-1,26-30 (In Russian: Nuzhno li razvivat v Rossii promyshlenniy turizm?).

3. Volkov, S.K. (2015)Industrial tourism: review of German experience and prospects for Russian regions. Management in Russia and abroad,5,68-75 (In Russian: Promyshlennyy turizm: obzor nemetskogo opyta i perspektivy dlya rossiyskikh regionov).

4. Garnov, A.P., Krasnobaeva, O.V. (2012) Urgency of the system formation of domestic industrial tourism. Bulletin of the Russian Economic University named after G.V. 
Plekhanov.2,60-63 (In Russian: Aktualnost sistemnogo formirovaniya otechestvennogo promyshlennogo turizma).

5. Grigorenko, T.N., Kazmina L.N. (2015)Priorities in the sphere of domestic and incoming tourism development in Russia these days. Bulletin of the National Academy of Tourism, 4,14-16 (In Russian: Prioritety v oblasti razvitiya vnutrennego i vyezdnogo turizma Rossii na sovremennom etape).

6. Dmitriev, G.S. (2016)Khabarovsk Territory - the region of industrial tourism development. Young Scientist,15-1, 60-62 (In Russian: Khabarovskiy kray - territoriya razvitiya promyshlennogo turizma).

7. Kadyrov, R.V. (2012) Tatarstan enterprises of polymer production as a recreational resource of industrial tourism: the issue formulation. Bulletin of the Kazan Technological University, 10, 123-125 (In Russian: Predpriyatiya polimernogo proizvodstva Tatarstana kak rekreatsionniy resurs promyshlennogo turizma: postanovka problemi).

8. Koreshkov, M.V., Derevnina S.E. (2015) Industrial tourism: familiarity with the production.Vocational education and labor market, 9-10,42-43 (In Russian: Promyshlenniy turizm: znakomstvo s proizvodstvom).

9. Kosyakova, A.A. (2016)Prospects for the industrial tourism development in Russia. Nauchnaya mysl, 1, 56-59 (In Russian: Perspektivy razvitiya promyshlennogo turizma v Rossii).

10. Medyanik, A.V., Tarabanovskaya S.V. (2016) On the importance of industrial tourism in the region development. Trends in Science and Education System of the modern world, 183,30-33 (In Russian: K voprosu o znachenii promyshlennogo turizma v razvitii regiona).

11. Nikulina, Yu.N. (2016)Industrial tourism development as a way to improve the quality of training the young professionals for the regional economy.Intelligence. Innovation. Investments, 3, 46-52 (In Russian: Razvitie promyshlennogo turizma kak sposob povysheniya kachestva podgotovki molodykh spetsialistov dlya ekonomiki regiona).

12. Nikulina, Yu.N.(2015) The role of industrial excursions in the formation of a competitive specialist. Economics and Entrepreneurship, No. 8 (part 1),589-593 (In Russian: Rol promyshlennykh ekskursiy v stanovlenii konkurentosposobnogo spetsialista).

13. Nikulina, Yu.N., Struzberg, G.V.(2015) Industrial tourism in the system of interaction between universities and enterprises: content and development prospects - Monograph.M: Publishing House "Pero", 188 p. (In Russian: Promyshlenniy turizm v sisteme vzaimodeystviya vuzov i predpriyatiy: soderzhaniye i perspektivy razvitiya). 
14. Pogorelova, N.V. (2012)Prospects for the tourism development in the region with industrial and agrarian specialization. Bulletin of the Volga State University of Service. Series: Economics, 24, 35-39 (In Russian: Perspektivy razvitiya turizma v regione s promyshlennoy i agrarnoy spetsializatsiyey).

15. Sklyarenko, S.A., Panchenko T.M., Selivanov I.A., Golovenko M.V. (2011)Prospects for the industrial tourism development in Russia. Russian Entrepreneurship,10-1,146-150 (In Russian: Perspektivy razvitiya promyshlennogo turizma v Rossii).

16. Struzberg, G.V., Dokashenko L.V. (2014)Potential of the Orenburg region in the sphere of industrial tourism.New University. Series: Economics and Law, 4,122-125 (In Russian: Potentsial Orenburgskoy oblasti v sfere promyshlennogo turizma).

17. Struzberg, G.V. (2013)Current state and prospects for the industrial tourism development.Infrastructure sectors of the economy: problems and development prospects, 3,147-151 (In Russian: Sovremennoye sostoyanie i perspektivy razvitiya promyshlennogo turizma).

18. Timofeev, N.V. (2014)The concept of industrial tourism development as a way to improve the economic well-being of St. Petersburg (in case of a shipbuilding cluster). Proceedings of the St. Petersburg State Economic University, 2, 142-145 (In Russian: Kontseptsiya razvitiya promyshlennogo turizma kak sposob povysheniya ekonomicheskogo blagosostoyaniya Sankt-Peterburga (na primere sudostroitelnogo klastera).

19. Uskova, T.V., Egorov V.K., Leonidova E.G. (2016) Tourism in the Russian Federation: opportunities for import substitution. Issues on the territory development, 4,32-46 (In Russian: Turizm v Rossiyskoy Federatsii: vozmozhnosti dlya importozameshcheniya).

20. Frolova, E.V., Kabanova E.E.(2016) The development of tourist attractiveness of Russian regions: current trends and management practices. Economic and social changes: facts, trends, forecast, 1,153-169 (In Russian: Razvitie turisticheskoy privlekatelnosti rossiyskikh territoriy: sovremenniye tendentsii i upravlencheskie praktiki).

21. Yashalova, N.N., Akimova M.A., Ruban D.A., Boyko S.V., Usova A.V., Mustafayeva E.R. (2017) Prospects for the regional development of industrial tourism in the light of the analysis of main economic indicators in the Russian tourism industry.Economic and social changes: facts, trends, forecast, Vol. 10. 2,195-213 (In Russian: Perspektivy regionalnogo razvitiya promyshlennogo turizma $\mathrm{v}$ svete analiza osnovnykh ekonomicheskikh pokazateley rossiyskoy turindustrii). 
22. Bran, F. ManeaG. (2012)The industrial tourism. Quality - Access to Success. Vol. 13, suppl. 3,1-6.

23. Boros, L, Martyin Z,Pal V.(2013) Industrial tourism - trends and opportunities. Forum Geographic / ed. by Studiisicercetari de geografiesiprotectiamediului. - Hungary, 108-114.

24. Bujok, P., Klempa M., Jelinek J., Porzer M., Rodriguez Gonzalez M.A.G. (2015)Industrial tourism in the context of the industrial heritage. Geojournal of Tourism and Geosites. Vol. 15,81-92.

25. Copic, S.,Dordevic J., Lukic T.,Stojanovic V., Dukicin, S., Besermenji, S., Stamenkovic, I., Tumaric A. (2014)Transformation of industrial heritage -an example of tourism industry development in the Ruhr area (Germany) . Geographica Pannonica, Vol. 18, 43-50.

26. Frew, E.A. (2008) Industrial tourism theory and implemented strategies. Advances in Culture, Tourism and Hospitality Research. Vol. 2,27-42.

27. Garaca, V., Trifkovic, A., Curcic, N.,VukosavS. (2014)Aspects of industrial heritage tourism: Case of Novi Sad.Revista de Cercetare si Interventie Sociala.Vol. 44,181-198.

28. Hospers, G.-J. (2002)Industrial heritage tourism and regional restructuring in the European union.European Planning Studies. Vol. 10,397-404.

29. Jia, Y. (2010)Analysis and Suggestions on Chinese Industrial Tourism Development. International Business Research. Vol. 3,169-173.

30. Jonsen-Verbeke, M. (1999) Industrial heritage: A nexus for sustainable tourism development. Tourism Geographies. Vol. 1,70-85.

31. Lee, C.-F. (2016) An investigation of factors determining industrial tourism attractiveness. Tourism and Hospitality Research. Vol. 16, 184-197.

32. Otgaar, A. (2012) Towards a common agenda for the development of industrial tourism.Tourism Management Perspectives. Vol. 4,86-91.

33. Otgaar, A. (2014)Industrial tourism: Where the Public Meets thePrivate.Rotterdam: Erasmus University of Rotterdam,260 p.

\section{How to cite this article:}

Nikulina Y N. Studying the features of industrial tourism development and operation in the region. J. Fundam. Appl. Sci., 2017, 9(2S), 1416-1444. 